\title{
ANALISIS LEARNING OBSTACLE SISWA SMA PADA MATERI FUNGSI INVERS
}

\author{
Amalia Pratamawati \\ SMAN 1 Tebing Tinggi Barat, Kabupaten Kepulauan Meranti, Riau \\ Email: amalia.pratamawati89@gmail.com
}

\begin{abstract}
Abstrak
Penelitian ini bertujuan untuk menganalisis karakteristik learning obstacle siswa SMA pada materi fungsi invers. Metode penelitian yang digunakan adalah metode penelitian kualitatif. Penelitian dilaksanakan di salah satu SMA Negeri di Kabupaten Kepulauan Meranti Provinsi Riau pada semester II tahun ajaran 2016/2017. Uji learning obstacle dilakukan pada siswa SMA kelas XII IPA. Teknik pengumpulan data learning obstacle siswa dilakukan dengan tes tertulis, wawancara, observasi, dan studi dokumentasi. Temuan hasil penelitian menunjukkan bahwa karakteristik learning obstacle siswa SMA pada materi fungsi invers antara lain didactical obstacles, ontogenic obstacles, dan epistemological obstacles.
\end{abstract}

Kata kunci: learning obstacle, matematika, fungsi invers.

\section{LATAR BELAKANG}

Salah satu konsep matematika yang harus dikuasai siswa pada jenjang SMA adalah konsep materi fungsi invers. Menurut beberapa studi yang relevan, disimpulkan bahwa siswa mengalami kesulitan atau miskonsepsi dalam mempelajari konsep fungsi invers (Okur, 2013; Carlson \& Oehrtman, 2005). Penyebab kesulitan dan kesalahpahaman tersebut berdasarkan kenyataan bahwa konsep fungsi invers umumnya diajarkan berdasarkan hafalan dan aturan rutin (Wilson, Adamson, Cox \& O’Bryan, 2011). Jenis pengajaran seperti ini dapat membuat siswa mengalami kesulitan untuk melakukan operasi dengan cara yang benar, memahami bagaimana konsep tersebut digunakan, dan menafsirkannya.

Wilson dkk. (2011) melaporkan bahwa ada dua jenis kesalahpahaman terkait dengan fungsi invers. Pertama, menulis invers dari fungsi $y=f(x)$ sebagai $y=f^{-1}(x)$. Hal ini merupakan kesalahan konseptual umum yang dibuat dalam menemukan invers suatu fungsi. Kedua, untuk memperoleh grafik fungsi invers dengan mencari simetrinya melalui pencerminan fungsi $f(x)$ terhadap garis $y=x$ pada koordinat kartesius. Penyebab kesalahan ini menurut Carlson \& Oehrtman (2005) adalah karena pada saat operasi penggantian yang berlangsung antara variabel $x$ dan $y$, sejak awal penggantiannya telah mengubah arti dari variabel.

Suatu studi dilakukan oleh Breen, Larson, Shea dan Petterson (2015) di Irlandia dan Swedia untuk menganalisis concept image siswa pada fungsi invers. Hasil studi tersebut menunjukkan bahwa concept image siswa terdiri atas aljabar, geometri, dan lebih banyak komponen formal, selain itu siswa di Irlandia dan Swedia menjelaskan fungsi invers sebagai pertukaran $x$ dan $y$, sebagai refleksi ataupun sebagai suatu balikan.

Merujuk hasil studi yang telah dilakukan oleh para peneliti tersebut, tidak menutup kemungkinan adanya kesulitan-kesulitan lain yang dialami siswa di sekolah lain yang belum teridentifikasi dan perlu ditemukan solusinya. Kesulitan-kesulitan tersebut tentunya akan menjadi hambatan bagi siswa dalam mempelajari matematika, khususnya dalam mempelajari materi fungsi invers.

\section{Fungsi Invers}

Fungsi invers merupakan fungsi balikan. Fungsi invers adalah fungsi yang dapat membatalkan fungsi lainnya. Fungsi akar kuadrat dan fungsi kuadrat adalah contoh dari fungsi invers dalam 
domain non-negatif. Tidak semua fungsi yang dibalik memiliki fungsi invers, tapi setiap fungsi memiliki hubungan balikan (invers). Jika balikan suatu fungsi merupakan fungsi maka disebut 'fungsi invers'. Jika balikan suatu fungsi bukan merupakan fungsi (hanya relasi), maka disebut 'invers suatu fungsi' (Okur, 2013).

Dalam berbagai penelitian tentang fungsi, terdapat penelitian mengenai pengembangan konsep fungsi invers (misalnya, Esty, 2005) atau miskonsepsi terkait dengan fungsi invers (misalnya, Okur, 2013; Carlson \& Oehrtman, 2005; Wilson dkk., 2011). Hanya sedikit penelitian yang berfokus pada fungsi invers (misalnya, Zazkis \& Kontorovich, 2016).

Dalam penelitiannya Zazkis dan Kontorovich (2016) menganalisis kesamaan simbol pangkat (-1) yang digunakan untuk menunjukkan invers dari fungsi dan timbal balik dari bilangan rasional. Dalam matematika terdapat simbol yang sama, yaitu pangkat (-1) yang digunakan untuk menunjukkan invers dari fungsi dan timbal balik dari bilangan rasional. Dalam konteks fungsi, $f^{-1}$ atau $f^{-1}(x)$ diartikan sebagai fungsi invers dari $f(x)$. Pilihan notasi ini juga terhubung ke konsistensi dalam penggunaan eksponen (Zazkis \& Kontorovich, 2016). Kita mungkin memeriksa apa yang diperlukan untuk menganggap $f^{-1}(x)$ agar hubungan dari $f^{m} f n(x)=f^{m+n}(x)$ dapat digunakan ketika $\mathrm{m}$ atau $\mathrm{n}$ adalah -1 . Misalkan $m=1$ dan $n=-1$; sehingga hubungan menjadi $f f^{-1}(x)=f^{0}(x)=x$. Jadi, $f^{-1}(x)$ harus menunjukkan jumlah dari fungsi $f$ adalah $x$. Artinya, fungsi $f$ diterapkan untuk $f^{-1}(x)$ hasilnya adalah $x$, dalam notasi ditulis dengan $f\left(f^{-1}(x)\right)=x$ (Zazkis \& Kontorovich, 2016).

\section{Learning Obstacle}

Setiap anak pada kenyataannya mengalami kesulitan-kesulitan yang menimbulkan hambatan (obstacle) dalam memahami dan menguasai matematika. Hambatan belajar yang dialami oleh siswa selanjutnya disebut dengan learning obstacle. Dalam buku yang ditulis oleh Brousseau $(1997 ; 2002)$ pengertian obstacle yaitu:

“...errors and failures do not have simplified role that we would like them to play. Errors are not only the effect of ignorance, of uncertainty, of chance, as espoused by empirist or behaviorist learning theories, but the effect of a previous piece of knowledge which was interesting and successful, but which now is revealed as false or simply unadapted. Errors of this type are not erratic and unexpected, they constitute obstacles" (pp. 82).

Berdasarkan pengertian tersebut, diketahui bahwa hambatan (obstacle) bukan kesalahan-kesalahan akibat dari ketidaktahuan, ketidakpastian, atau kesempatan, tetapi merupakan kesalahan yang tidak menentu dan tidak terduga yang mengakibatkan salah dalam proses memaknai pengetahuan yang telah diperoleh. Jadi, dapat disimpulkan bahwa learning obstacle merupakan hambatan belajar yang dialami oleh siswa karena adanya kesalahan dalam memaknai pengetahuan yang telah diperoleh berdasarkan pengalaman belajar sebelumnya.

Banyak kesalahan yang dilakukan siswa dalam mengerjakan soal, dapat menjadi petunjuk sejauh mana kesulitan dan penguasaan siswa terhadap materi tersebut. Dari kesalahan inilah dikaji kesulitan apa yang dialami oleh siswa dalam memahami materi yang diajarkan. Sumber kesalahan harus segera mendapatkan pemecahan yang tuntas. Pemecahan terhadap masalah yang dialami siswa dapat ditempuh dengan menganalisis akar permasalahan yang menjadi penyebab kesalahan yang dilakukan siswa (Susanti \& Yulaida, 2015).

Usaha-usaha untuk membantu siswa yang mengalami kesulitan belajar haruslah berlandaskan pada teori yang dapat diterima agar lebih mendatangkan hasil. Brousseau (1997; 2002) mengkategorikan learning obstacle menjadi tiga tipe;

"(1) ontogenic obstacles are obstacles of development, the obstacles associated with the stage of mental development of children according to age and biological development, (2) didactical obstacles are obstacle that arise as a result of learning options related to 
the education system, and (3) epistemological obstacles are the obstacles that arise from learning approach derived from the consept itself"'(pp. 86).

Dengan kata lain, learning obstacle dapat diidentifikasi berdasarkan tiga faktor, yaitu ontogenic obstacles (kesiapan mental belajar khususnya kematangan kognitif siswa untuk belajar), didactical obstacles (struktur kurikulum, sistem pengajaran guru atau bahan ajar), dan epistemological obstacles (pengetahuan konsep dan pengalaman belajar siswa yang terbatas pada konteks tertentu).

Dalam buku karangan Brousseau $(1997 ; 2002)$ terdapat beberapa karakteristik untuk mengenali learning obstacle, yaitu: 1) Obstacle merupakan bagian dari sebuah pengetahuan atau konsepsi, bukan sebuah kesulitan atau kurangnya pengetahuan; 2) Bagian pengetahuan itu menghasilkan respon yang tepat terhadap konteks tertentu sesuai dengan pengalamannya; 3) Tetapi hal tersebut menimbulkan kesalahan jika digunakan di luar konteks yang tidak sesuai dengan pengalamannya; 4) Akhirnya, siswa tetap bertahan dengan pengetahuan yang ada meskipun terjadi kontradiksi terhadap pengetahuan yang baru; 5) Sekalipun telah dikenali, obstacle yang dialami tetap terjadi pada saat tertentu. Tujuan penelitian ini adalah untuk menganalisis karakteristik learning obstacle siswa SMA pada materi fungsi invers.

\section{METODE PENELITIAN}

Metode penelitian yang digunakan dalam penelitian ini adalah metode penelitian kualitatif. Penelitian ini mendeskripsikan hasil analisis karakteristik learning obstacle siswa SMA pada materi fungsi invers. Teknik pengumpulan data adalah dengan triangulasi, yaitu 1) Tes Tertulis/ Tes Kemampuan Responden (TKR) digunakan untuk mengumpulkan data tentang bagaimana siswa menyelesaikan soal-soal yang berkaitan dengan materi fungsi invers; 2) Wawancara, dilakukan setelah responden melaksanakan TKR. Wawancara yang digunakan adalah wawancara tidak terstruktur; 3) Observasi, dilakukan untuk menganalisis buku teks pelajaran matematika yang digunakan guru pada proses pembelajaran fungsi invers sebelumnya; 4) Studi dokumentasi, dilakukan dengan mengumpulkan dokumen-dokumen kurikulum dan data-data yang diperlukan berupa bahan ajar matematika yang digunakan guru dan daftar nama siswa. Studi dokumentasi bertujuan untuk melengkapi observasi dan wawancara yang dapat mendukung dalam proses mengungkapkan dan mendeskripsikan hasil penelitian.

Subjek dalam penelitian ini adalah siswa kelas XII SMA di salah satu SMA Negeri di Kabupaten Kepulauan Meranti Provinsi Riau. Penelitian dilaksanakan pada semester genap tahun ajaran 2016/2017. Dari subjek tersebut dipilih beberapa responden yang teridentifikasi mengalami learning obstacle pada materi fungsi invers. Subjek tersebut dipilih karena mereka telah mempelajari materi fungsi invers.

\section{HASIL PENELITIAN DAN PEMBAHASAN}

Identifikasi karakteristik learning obstacle yang ada pada siswa dilakukan dengan Tes Kemampuan Responden (TKR) materi fungsi invers. TKR diikuti oleh siswa kelas XII IPA sebanyak 20 orang (jumlah siswa 23 orang, tidak mengikuti tes 3 orang). Berdasarkan hasil TKR tersebut, selanjutnya dipilih 5 orang siswa untuk dilakukan proses wawancara yang bertujuan untuk mengetahui secara langsung strategi siswa dalam menjawab soal. Siswa yang dipilih adalah siswa yang jawaban soal TKR nya menggambarkan adanya learning obstacle pada diri siswa. Berdasarkan hasil uji TKR dan wawancara tersebut diperoleh karakteristik learning obstacle sebagai berikut.

\section{Didactical Obstacle}

Didactical obstacle dapat dianalisis melalui kurikulum, seperti urutan materi pada struktur kurikulum, ketergantungan guru pada salah satu pilihan strategi pembelajaran atau kelemahan 
di dalam bahan ajar yang digunakan. Dari 20 orang siswa yang mengikuti TKR, hanya 1 orang siswa yang menjawab domain dari fungsi inversnya, itupun hanya untuk soal nomor 1b (Gambar $1)$.

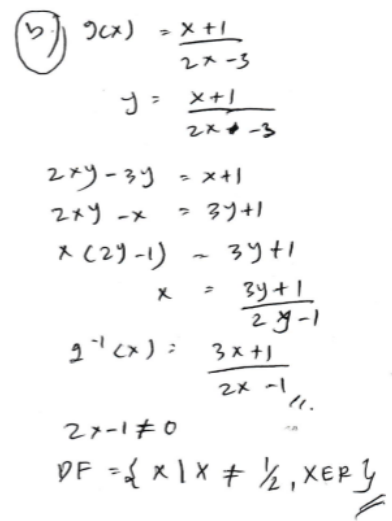

Gambar 1. Jawaban Soal Nomor 1b Tes Kemampuan Responden (TKR) Siswa 1 (Kode: S1)

Berdasarkan hasil wawancara dengan S1, terlihat bahwa S1 dapat menjawab domain dari soal nomor 1b karena S1 pernah menemui soal seperti itu karena pernah diajarkan. Tapi sebenarnya S1 tidak memahami konsep cara menentukan domain suatu fungsi, karena dari penjelasan alasan jawabannya, terlihat S1 bingung yang dia tahu hanya prosedur untuk mengerjakannya.

Selanjutnya, berdasarkan jawaban siswa 2 (S2) (Gambar 2), diketahui bahwa siswa dapat menjawab dengan benar rumus fungsi invers untuk masing-masing fungsi yang ditanyakan. Namun, siswa tidak dapat menentukan domain untuk masing-masing fungsi tersebut.
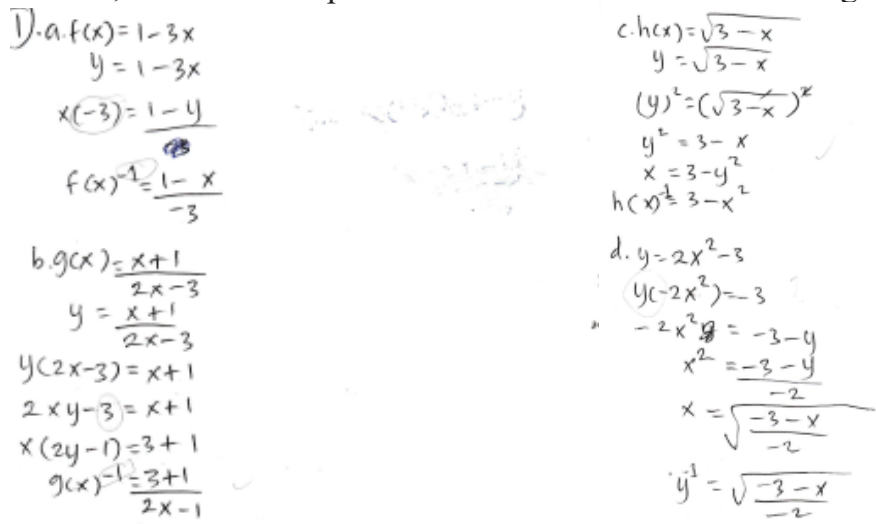

Gambar 2. Jawaban Soal Nomor 1 Tes Kemampuan Responden (TKR) Siswa 2 (Kode: S2)

Berdasarkan wawancara diketahui bahwa S2 tidak menjawab domain dari fungsi inversnya karena pada saat kelas XI siswa tidak diajarkan secara rinci cara menentukan domain dari rumus fungsi. S2 hanya mengingat cara menentukan domain, kodomain range yang dari diagram panah, yang diajarkan di SMP. Di SMP, S1 juga pernah mengetahui domain, kodomain range yang dari rumus fungsi, tapi karena hanya membaca dari buku dan tidak dijelaskan oleh guru, jadi siswa tidak memahaminya.

Berikutnya Siswa 3 (S3) juga mengalami hal yang sama dengan S2. Berdasarkan jawaban siswa 2 (Gambar 3), diketahui bahwa siswa dapat menjawab dengan benar rumus fungsi invers untuk masing-masing fungsi nomor 1a, 1b, dan 1c. Namun, siswa tidak dapat menentukan domain untuk masing-masing fungsi tersebut. 


$$
\begin{aligned}
& \begin{aligned}
1 \cdot a \cdot f^{-1}(x) & =1-3 x \\
y & =1-3 x \\
3 x & =-y+1 \\
x & =\frac{-y+1}{3} \\
f^{-1}(x) & =\frac{-x+1}{3}
\end{aligned} \\
& \text { b. } g(x)=\frac{x+1}{2 x-3} \\
& y=\frac{x+1}{2 x-3} \\
& y(2 x-3)=x+1 \\
& 2 x y-3 y=x+1 \\
& 2 x y-x=3 y+1 \\
& x(2 y-1)=3 y+1 \\
& x=\frac{3 y+1}{2 y-1}
\end{aligned}
$$

Gambar 3. Jawaban Soal Nomor 1 Tes Kemampuan Responden (TKR) Siswa 3 (Kode: S3) Berdasarkan wawancara diketahui bahwa S3 kurang teliti dalam menjawab soal nomor 1d, yaitu pada saat melakukan pindah ruas siswa lupa mengubah tanda $2 x^{2}$, seharusnya $-2 x^{2}$. Selanjutnya S3 tidak dapat menjawab domain dari fungsi inversnya karena merasa tidak ingat atau kurang dibaca. S3 hanya mengingat cara menentukan domain, kodomain range yang dari diagram panah. S3 juga pernah mengetahui domain, kodomain range yang dari rumus fungsi, tapi karena kurang dibahas dan tidak dijelaskan oleh guru jadi siswa tidak memahaminya.

Tidak jauh berbeda dengan S2 dan S3, siswa 4 (S4) juga mengatakan alasan yang sama mengapa S4 tidak bisa menjawab domain dari fungsi inversnya. Berikut ini cuplikan wawancara dengan S4.

$\mathrm{G}$ : Ee..terus..e..kenapa disitu kan pertanyaannya selain mencari fungsi inversnya kan juga harus mencari domainnya. Kenapa kamu gak nyari domainnya?

S4 : Karena saya lupa buk cari domainnya tu kayak mana.

$\mathrm{G}$ : Lupa cari domainnya. Ee..e..kalau cara cari domain yang kamu tau yang gimana?

S4 : Yang cara...kalau gak salah saya buk tapi...ingat caranya aja buk tapi gak ingat yang mana domainnya yang mana kodomainnya.

$\mathrm{G}$ : Ooh, yang mana tu maksudnya domain yang mana? Yang bentuk apa?

S4 : Saya tau bentuknya aja tapi buk, kalau seperti gini ka..ada himpunan A, himpunan B kalau gak salah saya buk, tu nantik tu diginikan di ini ada fungsi relasinya gitu.

Berdasarkan hasil analisis jawaban soal TKR dan hasil wawancara dengan S1, S2, S3 dan S4, diketahui bahwa siswa tidak dapat menentukan domain suatu fungsi invers akibat dari penyajian materi atau bahan ajar yang digunakan guru. Siswa mengakui bahwa cara menentukan domain fungsi pernah diajarkan di SMP dan juga kelas XI SMA, namun cara menentukan domain yang diajarkan dan diingat siswa adalah yang melalui diagram panah, sedangkan domain yang melalui rumus fungsi diajarkan tidak secara rinci atau hanya dibaca dari buku tetapi tidak dijelaskan cara menentukannya. Oleh karena itu, peneliti menyimpulkan bahwa siswa mengalami didactical obstacle akibat penyajian materi atau bahan ajar yang digunakan guru.

\section{Ontogenic Obstacle}

Ontogenic obstacle dapat muncul karena keterbatasan dalam perkembangan kognitif siswa. Misalnya siswa tidak menguasai pengetahuan materi prasyarat dengan baik, hal ini dapat menimbulkan hambatan ketika siswa mempelajari materi yang lebih tinggi karena siswa belum 
menguasai pengetahuan dasar yang harus dimilikinya untuk mempelajari materi tersebut.

Ontogenic obstacle pada siswa muncul ketika menjawab soal nomor 2, karena untuk menjawab soal ini diperlukan materi prasyarat yaitu siswa harus menguasai konsep eksponen dan logaritma, serta konsep menggambar grafik fungsi eksponen dan logaritma. Untuk dapat menggambar grafik fungsi eksponen dan logaritma siswa juga harus menguasai konsep menggambar grafik fungsi.

Berdasarkan jawaban Siswa 1 (Gambar 4), didapatkan kesalahan siswa dalam menuliskan rumus fungsi inversnya dan kesalahan pada gambar grafik fungsinya. Untuk mengetahui learning obstacle siswa dalam menjawab soal tersebut dilakukanlah wawancara.
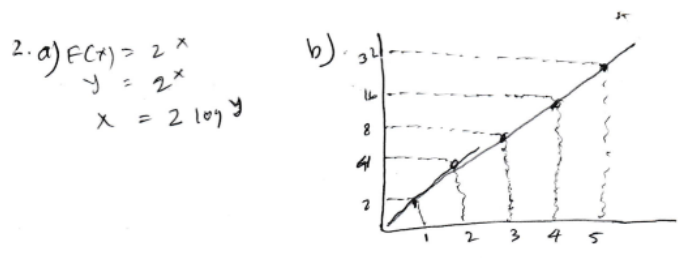

Gambar 4. Jawaban Soal Nomor 2 Tes Kemampuan Responden (TKR) Siswa 1 (Kode: S1)

Dari wawancara dengan S1, siswa menganggap bahwa $y$ itu merupakan pangkat dari 2 log. Peneliti mencoba memastikan dan siswa yakin bahwa jawabannya 2 log pangkat $y$.

$\mathrm{G}$ : Nah, jadi inversnya berapa berarti dari $2^{\mathrm{x}}$, yang mana inversnya?

S1: ee.. inversnya jadi, 2 log pangkat $y$.

Peneliti bertanya kembali apa invers dari fungsi $f(x)=2^{x}$, berharap siswa tersebut menyadari kesalahannya bahwa jawabannya seharusnya bukan $2 \log$ pangkat $y$ tapi seharusnya $\log y$ basis 2 $\left({ }^{2} \log y\right)$, namun $\mathrm{S} 1$ tetap menjawab bahwa inversnya adalah $2 \log$ pangkat $y$.

Dari lembar jawaban dan wawancara tersebut, peneliti menyimpulkan bahwa S1 mengalami ontogenic obstacle, karena S1 tidak menguasai konsep eksponen dan logaritma dengan baik. Siswa tidak memahami bagaimana cara merubah bentuk pangkat menjadi logaritma dan bagaimana cara menulis logaritma yang benar. Siswa mengalami keterbatasan dalam perkembangan kognitifnya pada konsep eksponen dan logaritma.

Keterbatasan perkembangan kognitif siswa pada konsep eksponen dan logaritma tergambar pula pada saat menjawab soal menggambar grafik fungsi eksponen dan logaritma.

$\mathrm{G}$ : Ini kamu dapatkan dari mana? Ini grafik fungsi $f(x)$ apa grafik fungsi inversnya?

S1 : fungsi.. Oh iya, ini diminta dia..ini..in...grafik..ntar buk.

$\mathrm{G}: f(x)$ ? $f$ inversnya?

$\mathrm{S} 1$ : Ini grafik inversnya

$\mathrm{G}$ : Dari mana kamu dapatkan? Kenapa ini..seperti ini jadinya gambarnya?

S1 : Kan kalau pemisalan angkanya itu..terus dari 1, 2, 3, 4, 5 untuk yang di bawahnya. Terus yang diatas ini kelipatannya...bukan kelipatan..eee..misalnya 2 dikali 2 dapatnya 4..nanti 4 dikali 2 lagi dapat 8, 8 dikali 2 lagi dapat 16, 16 dikali 2 lagi dapatnya 32, jadi dibuatlah suatu diagram yang 1 nya ke 2,2 nya ke 4 , dan seterusnya.

$\mathrm{G}$ : Kenapa pake kali 2, berarti pake rumus yang mana? Rumus yang $f(x)$ atau yang hasilnya tadi yang $2 \log$ pangkat apa tadi $y$, gak dimasukkan kesitu?

S1 : Pake rumus yang $f(x)=2^{X}$ tadi.

Dari lembar jawaban dan wawancara tersebut, terlihat bahwa siswa tidak mengerti gambar apa sebenarnya yang sedang dibuatnya. Perhatikan pula diagram cartesius yang dibuat siswa untuk menggambar grafiknya, tidak ada skala pada gambar grafik tersebut sehingga menghasilkan grafik yang salah. Hal ini menunjukkan siswa tidak menguasai konsep dasar cara menggambar grafik fungsi, sehingga siswa juga terkendala dalam menggambar grafik fungsi eksponen dan logaritma. 
Siswa 4 (S4) juga mengalami ontogenic obstacle seperti yang dialami siswa 1 (S1). Berdasarkan jawaban Siswa 4 (Gambar 5), didapatkan kesalahan siswa dalam menuliskan rumus fungsi inversnya dan kesalahan pada gambar grafik.
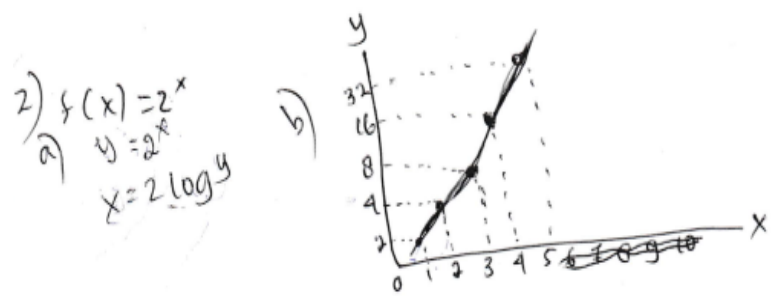

Gambar 5. Jawaban Soal Nomor 2 Tes Kemampuan Responden (TKR) Siswa 4 (Kode: S4)

Berdasarkan wawancara, dapat dipastikan bahwa siswa menjawab $2 \log y$ dan ditulis sejajar semua. Siswa sepertinya menganggap bahwa 2 berada di depan $x$ sehingga 2 merupakan koefisien $x$. Jadi 2 dapat dipindahruaskan seperti koefisien.

Dari lembar jawaban dan wawancara tersebut, peneliti menyimpulkan bahwa S4 juga mengalami ontogenic obstacle, karena S4 tidak menguasai konsep eksponen dan logaritma dengan baik. S4 tidak memahami bagaimana cara merubah bentuk pangkat menjadi logaritma dan bagaimana cara menulis logaritma yang benar. S4 mengalami keterbatasan dalam perkembangan kognitifnya pada konsep eksponen dan logaritma.

Keterbatasan perkembangan kognitif siswa pada konsep eksponen dan logaritma tergambar pula pada saat menjawab soal menggambar grafik fungsi eksponen dan logaritma (Gambar 5)

$\mathrm{G}$ : Lalu, ee.. kalau grafiknya, gimana cara dapatinnya?

S4 : Kalau grafik, ini kalau, kalau saya cari ini, $y$, kan $y=2^{x}$. Jadi $x$ nya itu saya masuk nilai yang paling mudah saya masukkan buk, misalkan nye $x$ itu $2^{l}$ hasilnya 2 , gitu buk. Saya masuk sampai $2^{5}$ hasilnya 32 , itu langsung saya buat grafiknya.

$\mathrm{G}$ : ee..grafiknya bentuknya apa? Apakah garis lurus atau tidak?

S4 : Garis..garis lurus buk.

Dari lembar jawaban dan wawancara tersebut, terlihat bahwa S1 dan S4 tidak menguasai konsep menggambar grafik fungsi. Diagram cartesius yang dibuat siswa untuk menggambar grafiknya, tidak ada skala pada gambar grafik tersebut sehingga menghasilkan grafik yang salah yaitu grafik berbentuk garis lurus. Apabila siswa membuat dengan skala yang benar, siswa seharusnya mendapatkan grafik eksponen yang benar. Hal ini menunjukkan siswa tidak menguasai konsep dasar cara menggambar grafik fungsi, sehingga siswa juga terkendala dalam menggambar grafik fungsi eksponen dan logaritma.

\section{Epistemological Obstacle}

Epistemological obstacle adalah hambatan belajar siswa yang disebabkan karena faktor pengetahuan konsep dan pengalaman belajar siswa yang terbatas pada konteks tertentu. Pengetahuan konsep yang dimiliki siswa dapat berfungsi dengan baik dalam beberapa permasalahan tertentu, tetapi karena pengalaman belajar siswa yang terbatas, pengetahuan itu kemudian tidak dapat bekerja baik pada konteks lainnya.

Epistemological obstacle pada siswa muncul ketika menjawab soal nomor 3 karena untuk menjawab soal ini siswa harus dapat menggunakan konsep invers fungsi untuk menentukan invers dari suatu fungsi komposisi. Siswa memahami konsep fungsi komposisi dan juga memahami konsep fungsi invers, namun saat menentukan fungsi invers dari suatu fungsi komposisi siswa bingung untuk menggunakan konsepnya. 
Berdasarkan jawaban Siswa 4 (Gambar 6), didapatkan kesalahan siswa dalam menggunakan rumus fungsi komposisi. Untuk mengetahui learning obstacle siswa dalam menjawab soal tersebut dilakukanlah wawancara.

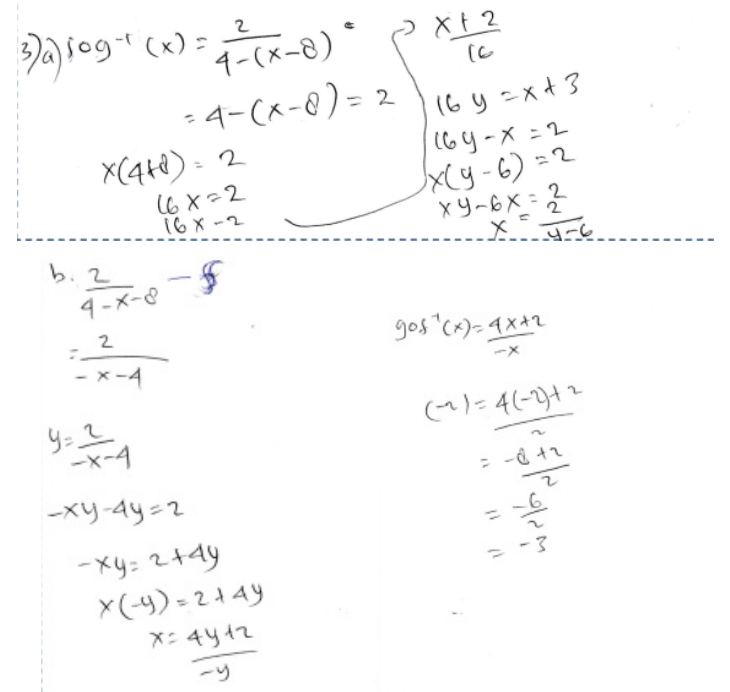

Gambar 6. Jawaban Soal Nomor 3 Tes Kemampuan Responden (TKR) Siswa 4 (Kode: S4) Berdasarkan wawancara terlihat bahwa siswa menganggap $f \circ g$ dan invers $f \circ g$ adalah suatu pertanyaan yang sama. Siswa mulai menjawab soal tersebut dengan mencari $f o g$, tapi siswa menuliskan $(f \circ g)^{-1}$ di lembar jawabannya. Siswa sepertinya kebingungan apakah harus menggunakan konsep fungsi komposisi atau fungsi invers terlebih dahulu. Selain itu S4 juga menganggap bahwa $f$ o $g$ adalah nilai $f$ yang dimasukkan ke $g$. Sedangkan $g$ of adalah nilai $g$ yang dimasukkan ke $f$.

Dengan demikian dapat diyakini bahwa siswa melakukan kesalahan dalam menetukan invers dari suatu fungsi komposisi karena siswa kesulitan saat harus menggunakan konsep fungsi komposisi dan konsep fungsi invers secara bersamaan. Hal ini juga menyebabkan siswa melakukan kesalahan saat mencari $f \circ g$ dan $g o f$, karena siswa menganggap komposisi tersebut langsung diinverskan sehingga $f \circ g$ adalah $f$ yang di masukkan ke $g$, dan sebaliknya $g$ of adalah $g$ yang dimasukkan ke $f$.

Berikutnya masih di soal nomor 3, siswa 5 (S5) melakukan kesalahan yang berbeda dengan S4 dalam menjawab soal tersebut. Kesalahan diidentifikasi pada soal nomor 3b (Gambar 7)

$$
\begin{aligned}
b \cdot g 0 F & =g(F x) \\
& =\frac{2}{4-(x-8)} \\
y & =\frac{2}{-4-x} \\
y-(-4-x) & =2 \\
-4 y-x y & =2 \\
-x y & =4 y+2 \\
x(-y) & =4 y+2 \\
x & =\frac{4 y-2}{-y} \\
(g O F)^{-1}(-2) & =\frac{4(-2)-2}{-2}=\frac{-8-2}{-2}
\end{aligned}
$$

Gambar 7. Jawaban Soal Nomor 3 Tes Kemampuan Responden (TKR) Siswa 5 (Kode: S5) 
Berdasarkan jawaban tersebut, teridentifikasi bahwa siswa 5 (S5) melakukan kesalahan dalam proses perkalian aljabar. Peneliti menduga bahwa kesalahan terjadi karena S5 kurang teliti. Namun, melalui hasil wawancara dengan S5 dapat diyakini bahwa kesalahan yang dilakukannya bukan karena tidak teliti. Tapi, kesalahan terjadi karena S5 yakin bahwa konsep perkalian aljabarnya sudah benar yaitu $-(-8)$ hasilnya adalah -8 , padahal seharusnya +8 . Hal ini terjadi konsep perkalian aljabar yang dipahami siswa masih terbatas pada konsep tertentu, ketika ada perkalian dengan negatif siswa tidak dapat menjawab dengan benar.

\section{KESIMPULAN DAN SARAN}

Karakteristik learning obstacles yang dialami siswa dalam mempelajari materi fungsi invers antara lain didactical obstacles yang terjadi karena pembelajaran yang hanya berpedoman pada bahan ajar berupa buku teks pelajaran matematika yang digunakan guru, sehingga siswa mengalami hambatan ketika dihadapkan pada pengetahuan yang tidak dijelaskan di dalam buku teks dan tidak pula dijelaskan oleh guru. Selain itu, ontogenic obstacles yaitu hambatan dalam menentukan invers dari fungsi eksponen dan menggambar grafik fungsi eksponen karena tidak menguasai materi prasyarat, yaitu fungsi eksponen dan logaritma dan grafik fungsi eksponen dan logaritma. Hal ini menimbulkan epistemological obstacles yaitu hambatan dalam menentukan invers dari suatu fungsi komposisi karena tidak dapat mengaitkan antara rumus fungsi komposisi dengan rumus fungsi invers dan kesalahan operasi aljabar.

Perlu dilakukan penelitian lebih mendalam pada penguasaan konsep matematika siswa yang menjadi prasyarat dalam mempelajari materi fungsi invers terutama operasi bentuk aljabar, relasi dan fungsi, menggambar grafik fungsi, serta eksponen dan logaritma. Hal ini dikarenakan penguasaan materi prasyarat tersebut akan sangat mempengaruhi proses pembelajaran pada materi fungsi invers.

\section{DAFTAR RUJUKAN}

Breen, S., Larson, N., 'Shea, A.O., \& Pettersson, K. (2015). Student's concept images of inverse functions. CERME 9- Ninth Congress of the European Society for Research in Mathematics Education, pp. 2228-2234, Prague, Czech Republic.

Brousseau, G. (1997). Theory of Didactical Situation in Mathematics. London: Kluwer Academic Publisher.

Brousseau, G. (2002). Theory of Didactical Situation in Mathematics. London: Kluwer Academic Publisher.

Carlson, M. \& Oehrtman, M. (2005). Research sampler 9: Key aspects of knowing and learning the concept of function. Retrieved June 29, 2017, from The Mathematical Association of America Research Sampler, http:/www.maa.org/programs/faculty-and-departments/ curriculum-department-guidelines-recommendations/teaching-and-learning/9-keyaspects-of-knowing-and-learning-the-concept-of-function.

Esty, W. (2005). Teaching about Inverse Functions. The AMATYC Review, 26(2), pp. 1-10.

Okur, M. (2013). Learning difficulties experienced by students and their misconceptions of the invers function concept. Academic Journals, 8(12), pp. 901-910.

Susanti, N.I. \& Yulaida, S. (2015). Analisis kesulitan siswa dalam pemahaman materi fungsi komposisi siswa kelas xi semester 2 MAN Pesanggaran tahun pelajaran 2014-2015. Pancaran, 4(4), pp. 99-112.

Wilson, F.C., Adamson, S., Cox, T. \& O’Bryan, A. (2011). Inverse Functions what our teachers didn't tell us. Mathematics Teacher, 104, pp. 501-507.

Zazkis, R. \& Kontorovich, I. (2016). A curious case of superscript (-1): Prospective secondary mathematics teachers explain. Journal of Mathematics Behavior, 43, pp. 98-110. 